\title{
Review \\ Nuclear RNA Exosome and Pervasive Transcription: Dual Sculptors of Genome Function
}

\author{
Koichi Ogami ${ }^{1}\left[\right.$ and Hiroshi I. Suzuki ${ }^{1,2, *}$ (D) \\ 1 Division of Molecular Oncology, Center for Neurological Diseases and Cancer, Nagoya University Graduate \\ School of Medicine, 65 Tsurumai-cho, Showa-ku, Nagoya 466-8550, Japan; koichi.ogami@med.nagoya-u.ac.jp \\ 2 Institute for Glyco-core Research (iGCORE), Nagoya University, Furo-cho, Chikusa-ku, \\ Nagoya 464-8601, Japan \\ * Correspondence: hisuzuki@med.nagoya-u.ac.jp; Tel.: +81-52-744-2459
}

Citation: Ogami, K.; Suzuki, H.I. Nuclear RNA Exosome and Pervasive Transcription: Dual Sculptors of Genome Function. Int. J. Mol. Sci. 2021, 22, 13401. https://doi.org/ $10.3390 /$ ijms222413401

Academic Editors: Naoyuki Kataoka and Rui Henrique

Received: 25 November 2021 Accepted: 10 December 2021 Published: 13 December 2021

Publisher's Note: MDPI stays neutral with regard to jurisdictional claims in published maps and institutional affiliations.

Copyright: (C) 2021 by the authors. Licensee MDPI, Basel, Switzerland. This article is an open access article distributed under the terms and conditions of the Creative Commons Attribution (CC BY) license (https:// creativecommons.org/licenses/by/ $4.0 /)$.

\begin{abstract}
The genome is pervasively transcribed across various species, yielding numerous noncoding RNAs. As a counterbalance for pervasive transcription, various organisms have a nuclear RNA exosome complex, whose structure is well conserved between yeast and mammalian cells. The RNA exosome not only regulates the processing of stable RNA species, such as rRNAs, tRNAs, small nucleolar RNAs, and small nuclear RNAs, but also plays a central role in RNA surveillance by degrading many unstable RNAs and misprocessed pre-mRNAs. In addition, associated cofactors of RNA exosome direct the exosome to distinct classes of RNA substrates, suggesting divergent and/or multi-layer control of RNA quality in the cell. While the RNA exosome is essential for cell viability and influences various cellular processes, mutations and alterations in the RNA exosome components are linked to the collection of rare diseases and various diseases including cancer, respectively. The present review summarizes the relationships between pervasive transcription and RNA exosome, including evolutionary crosstalk, mechanisms of RNA exosome-mediated RNA surveillance, and physiopathological effects of perturbation of RNA exosome.
\end{abstract}

Keywords: RNA exosome; pervasive transcription; cofactor; genome; evolution; disease

\section{Introduction}

Precise spatio-temporal control of gene expression is critical for converting genomic information into biological functions of life systems. Transcription forms an initial foundation of the gene expression programs; eukaryotic genomes, including those of yeasts, are pervasively transcribed beyond the canonical protein-coding genes and representative non-coding RNA genes, such as rRNAs, yielding numerous RNA species such as long non-coding RNAs (lncRNAs), upstream antisense RNAs (uaRNAs, also known as promoter upstream transcripts (PROMPTs) in mammals or cryptic unstable transcripts (CUTs) in yeasts), transcription start site (TSS)-associated RNAs (tssRNAs), and enhancer RNAs (eRNAs) [1,2]. Typically, these RNA species are unstable and subject to rapid degradation by the RNA exosome complex, a counterbalance system for pervasive transcription. The RNA exosome not only regulates the processing of stable RNA species such as rRNAs, tRNAs, small nucleolar RNAs (snoRNAs), and small nuclear RNAs (snRNAs), but also plays a central role in RNA surveillance by degrading many unstable RNAs and misprocessed pre-mRNAs [3,4]. Besides these "classical" exosome substrates, the spectrum of exosome target transcripts is still expanding. In addition, associated cofactors of RNA exosome direct the exosome to distinct classes of RNA substrates, suggesting divergent and/or multi-layer control of RNA quality in the cell [3-5]. The present review summarizes the relationships between pervasive transcription and RNA exosome, including evolutionary crosstalk, mechanisms of RNA exosome-mediated RNA surveillance, and physiopathological effects of perturbation of RNA exosome. While the RNA exosome has been well 
studied in various species including yeasts and flies, this review mainly focuses on the findings in mammalian cells.

\section{Molecular Mechanisms of RNA Surveillance by RNA Exosome}

\subsection{Structure of RNA Exosome}

The structure and composition of RNA exosome are well conserved among eukaryotes and archaea, and a similar complex has been identified in bacteria [6]. The human nuclear RNA exosome consists of a catalytically inactive core complex (EXO9) with nine proteins and two catalytic subunits, EXOSC10 (also known as rRNA-processing protein 6 (Rrp6) or PM/Scl-100) and DIS3 (also known as Rrp44 or EXOSC11) (Figure 1) [7]. The barrel-shaped core complex can further be divided into two characteristic complexes: a cap structure comprising three S1/K homology $(\mathrm{KH})$ proteins (EXOSC1-3, also known as Rrp4, Rrp40, and Csl4) ("S1/KH cap") and a ring structure comprising six RNase pleckstrin homology (PH)-like proteins (EXOSC4-9, also known as Rrp41, Rrp42, Rrp43, Rrp45, Rrp46, and Mtr3) ("PH ring or barrel") (Figure 1a) [7]. The top of the S1/KH cap is an RNA entry pore, and the bottom of the PH barrel is an RNA exit pore. EXOSC10 and DIS3 are placed near the RNA entry and at the exit pore, respectively (Figure 1a). RNA substrates can either be degraded or $3^{\prime}$ trimmed by EXOSC10 or DIS3. Three distinct pathways leading an RNA to either of these proteins were discovered in budding yeast (Figure 1b) [8-14]. The threading pathway, in which an RNA is threaded into the central channel of the core complex in a $3^{\prime}-5^{\prime}$ orientation, depends on Rrp44 (the yeast homolog of DIS3) at the exit pore to degrade the RNA. In the traversing pathway, RNA enters the S1/KH cap ring, but, instead of threading into the barrel, the $3^{\prime}$ end of RNA traverses the cap. Rrp6 (the yeast homolog of EXOSC10) at the top of the cap is responsible for the degradation or trimming of the traversed RNA. The third pathway is the direct access of RNA to Rrp44 without entering the core structure. Recent studies using cryogenic electron microscopy (cryo-EM) have also successfully captured the structure of the threading human nuclear exosome $[15,16]$. It remains unclear whether the traversing and direct pathways exist in the human exosome system.

A recent proteomic analysis of cell cycle-dependent protein interactions suggests that the dynamics of EXOSC components can be divided into three groups: (1) PH ring components (EXOSC4-9) and EXOSC2, (2) EXOSC1 and EXOSC3, and (3) EXOSC10 [17]. EXOSC1, EXOSC3, and EXOSC10 are less stably associated with the core exosome complex than the other EXO9 subunits, possibly suggesting that these proteins have independent functions outside of the exosome complex $[18,19]$. Indeed, the exosome-independent functions of EXOSC1 have been suggested [19].

\subsection{Sorting of Target RNAs by Adaptors and Cofactors of RNA Exosome}

While the RNA exosome can degrade most RNA per se, multiple distinct adaptor complexes have been shown to direct the RNA exosome to distinct classes of RNA substrates (Figure 2). In most organisms, the RNA exosome has distinct partners in the nucleolus and nucleoplasm, although the Trf4/5-Air1/2-Mtr4 polyadenylation (TRAMP) complex plays a predominant role in both the nucleolus and nucleoplasm in Saccharomyces cerevisiae. In humans, the TRAMP complex consists of MTR4 (also known as SKIV2L2 or MTREX) and human homologs of the yeast Trf4/5 and Air1/2, non-canonical poly(A) polymerase PAPD5 (also known as hTrf4-2 or TENT4B) and ZCCHC7, respectively [20]. In contrast to budding yeast, the human TRAMP is restricted to the nucleolus and is involved in rRNA processing [20]. 

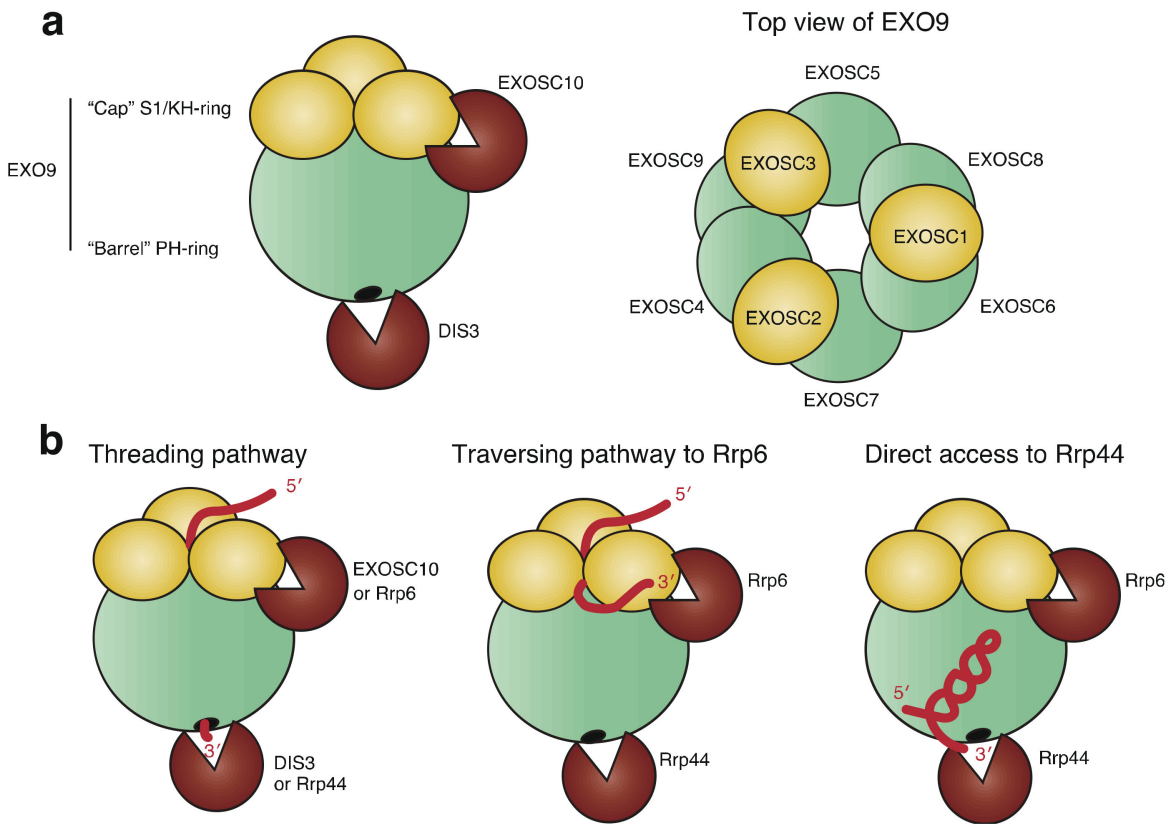

Figure 1. Structure of RNA exosome and pathways leading RNA substrates to the catalytic subunits. (a) The core RNA exosome (EXO9) is composed of nine subunits and is further divided into two structures, "cap" S1/KH ring and "barrel" PH-ring. Two catalytic subunits EXOSC10 and DIS3 are placed near the cap and at the bottom of barrel, respectively. (b) Three distinct pathways identified so far, which lead RNA $3^{\prime}$ end to either of the two catalytic subunits. Threading pathway: RNA is threaded into the central channel of the core exosome and brought to the active site of DIS3; Traversing pathway to Rrp6: RNA traverses the cap structure, reaching the active site of Rrp6; and Direct access to Rrp44: RNA directly accesses Rrp44 without entering the central channel.

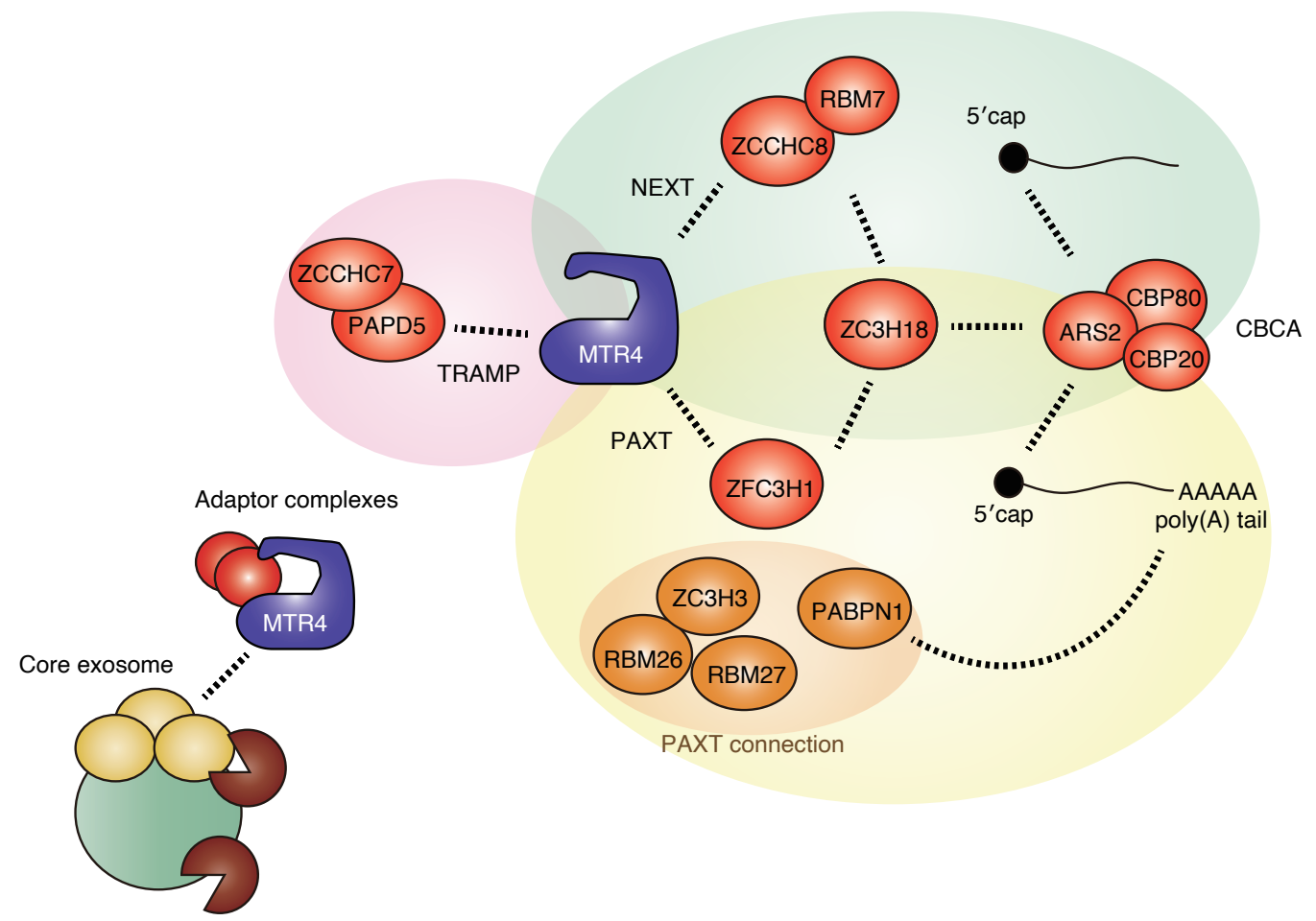

Figure 2. The human adaptor complexes guiding specific RNA substrates for exosome-mediated RNA degradation or processing. Note that the RNA helicase MTR4 is commonly present in all the adaptor complexes. 
In addition to the TRAMP complex, additional nucleoplasmic adaptor complexes have been identified in mammals. The nuclear exosome targeting complex (NEXT) and the poly(A) tail exosome targeting complex (PAXT) remove various types of nucleoplasmic lncRNAs, and many components of these complexes are conserved in Schizosaccharomyces pombe, especially PAXT. The NEXT complex consists of MTR4, the RNA-binding protein RBM7, the zinc-finger protein ZCCHC8, and degrades snRNA, snoRNA, replicationdependent histone mRNAs, uaRNAs, eRNAs, and LINE1 RNAs [20-22]. The PAXT complex consists of MTR4 and the zing-finger protein ZFC3H1 and functions in cooperation with the nuclear poly(A)-binding protein PABPN1 [23]. Three additional RNA-binding proteins, ZC3H3, RBM26, and RBM27, are required for the full activity of PAXT [24]. The PAXT complex targets snoRNA host gene (SNHG) transcripts, pre-mRNAs cleaved and polyadenylated in an intron (prematurely terminated RNAs; ptRNAs), uaRNAs, and eRNAs $[23,25]$. While the targets of NEXT and PAXT overlap, PAXT targets tend to be longer and more extensively polyadenylated than NEXT targets [23]. Promiscuous RNA binding by RBM7 with some preferences for U-rich pyrimidine stretches and recognition of poly(A) tails by PABPN1 appear to have important roles in target selection by NEXT and PAXT, respectively [22,23]. In addition, the connection between NEXT/PAXT and the cap-binding complex CBCA, which consists of cap-binding proteins CBP20 (also known as NCBP2), CBP80 (also known as NCBP1), and ARS2 (also known as SRRT) with ZC3H18, supports the physical interaction between NEXT/PAXT and capped RNAs $[20,23,26,27]$. Notably, MTR4 is present in all other adaptor complexes and thus plays a central role in complex assembly and RNA sorting.

A recent report has shown that NEXT targets become polyadenylated upon NEXT inhibition and are handed over to PAXT-mediated decay, indicating fail-safe RNA decay via PAXT [28]. This may be consistent with the deep conservation of PAXT components from fission yeast to humans, relative to NEXT components. Given that NEXT targets non-polyadenylated RNA $3^{\prime}$ ends distributed over kilobase-wide regions [28], NEXT may be adapted for the quality control of transcription of longer genes in higher organisms, as gene length in mammals is longer than that in yeast.

\subsection{Balance between RNA Export and Degradation}

CBCA (especially ARS2) plays an important role in determining whether target RNAs are subjected to productive processing and export or to nuclear retention and decay [29]. CBCA-bound mRNAs and snRNA/snoRNAs are directed toward productive processing by CBCA-associated nuclear export factor ALYREF and phosphorylated adaptor for RNA export (PHAX), respectively. ZC3H18, a CBCA-NEXT and CBCA-PAXT partner, physically competes with PHAX for CBCA binding, and these proteins oppositely define the fate of RNAs: degradation or export $[23,30]$. PHAX and ZC3H18 only transiently bind to CBC (CBP20/CBP80) and exchange rapidly and continuously on the CBC during transcription, allowing determination of the fate of RNAs at particular checkpoints [30]. As for replication-dependent histone mRNA, CBCA-associated FLASH commits these transcripts for maturation [31]. Similar to other exosome targets, replication-dependent histone $\mathrm{mR}$ NAs accumulate upon ARS2 depletion [26,32]; however, the competition between FLASH and the exosome adaptors for CBCA binding has not been experimentally examined.

Recent studies have revealed that PAXT plays an important role in balancing RNA degradation and export. Depletion of MTR4 and ZFC3H1 has been shown to cause accumulation of uaRNAs and ptRNAs not only in the nucleoplasm but also in the cytoplasm, resulting in cytoplasmic accumulation of abnormally ribosome-bound RNAs [25,33]. One explanation for the cytoplasmic leakage of PAXT targets observed under PAXT depletion is that MTR4 physically competes with ALYREF for association with ARS2 [34]. Importantly, compartmentalized distribution of RNAs seems to be a key to understanding RNA degradation-export balancing. When the nuclear exosome is depleted, the excessive formation of polyA+ RNA foci in the nucleus is reproducibly observed [34,35]. Although the full composition of the polyA+ RNA foci is yet to be determined, it at least includes all the 
PAXT components as well as SNHG RNAs and exosome target mRNAs [34,35]. The formation of the foci depends on the condensation activity of ZFC3H1 through its $\mathrm{N}$-terminal intrinsically disordered region [36], and the depletion of ZFC3H1 results in disruption of the nuclear polyA+ foci formed upon exosome inactivation [35,36]. Therefore, ZFC3H1 functions not only as a degradation factor but also as a nuclear RNA retention factor.

An additional important factor is the MTR4-binding partner NRDE2. NRDE2 interacts with MTR4 in a 1:1 stoichiometry, but the complex is devoid of the core exosome complex and is independent of the other adaptor complexes [37,38]. NRDE2 is enriched in nuclear speckles co-localized with polyA RNAs and represses exosome-mediated RNA degradation [38]. NRDE2 knockdown also affects RNA export, which is not due to the suggested intron retention, indicating that NRDE2-containing speckles are additional layers that control the balance between RNA degradation and export [38].

\section{Evolutionary Interplays between RNA Exosome and Pervasive Transcription}

How many of the unstable transcripts targeted by RNA exosome have biological functions? An ostensibly wasteful process of pervasive transcription and subsequent degradation by the RNA exosome may be reconciled with their evolutionary interplay. A recent review of lncRNAs provides insights into this issue [39]. In contrast to coding sequences, less than $10 \%$ of human genomic DNA is estimated to evolve under purifying selection [39]. Thus, the majority of genomic targets of pervasive transcription are considered to have evolved neutrally. In fact, overall, lncRNAs are considerably less conserved than untranslated regions (UTRs) of mRNAs, suggesting an inherent plastic nature [40]. In the evolutionary scenario, where eukaryotes evolve under a weak selection regime with genetic drift, it is unlikely that lncRNAs are maintained by positive selection in general. In the weak selection regime, promiscuity of the eukaryotic transcription machinery, including divergent transcription by RNA polymerase II and recognition of short and degenerative motifs by transcription factors, yields numerous RNA species without conserved functions, as even most of the heterochromatin is also transcribed [1,41,42]. The population genetic standpoint raises the hypothesis that organisms with small effective population size evolve the RNA exosome system as global solutions to deal with local problems, i.e., mutations that create a cryptic transcript; otherwise, the deleterious effects of transcription-inducing mutations cannot be efficiently eliminated from the population in the weak selection regime [39]. Global repression of unstable transcripts but allowance for low expression is thought to leave room for functional innovation to evolve the functionality of lncRNAs.

Furthermore, the introduction of the "constructive neutral evolution (CNE)" mechanism may help to understand step-by-step evolution from pervasive transcription to the acquisition of functionality of lncRNAs [39]. In the CNE-like processes, new mutations are created by non-adaptive (neutral) processes. While such mutations are neutral or often slightly deleterious ("presuppressing"), they give the organisms "excess capacity" that facilitates mutational decay of the original components and leads to the generation of novel components, interactions, and functions in part through adaptive selection [43]. When adapting CNE-like processes to the interpretation of pervasive transcription, the excess capacity of pervasive transcription is considered as negative and positive cis-regulatory effects of cryptic transcription and the transcripts, including eRNAs, on nearby genes [40]. Such excess capacity may allow the original regulatory transcription sites or transcripts to mutational decay, which will later be maintained and elaborated by acquiring sequence contexts to define transcriptional directionality, termination, RNA localization, RNA structure, and functionality including both non-coding and coding functions. Under these scenarios, the production of RNA is initially sustained by selection for transcription rather than by the transcript sequence, but eventually, the latter gains function. Thus, lncRNAs can be inherently considered as byproducts of transcription, so-called "spandrel" in evolutional biology $[39,44]$. This evolutionary trajectory is in contrast to that of protein-coding genes that mostly originate from gene duplication $[45,46]$. This model is overall consistent with widespread and multifaceted local interactions of lncRNAs and eRNAs with nearby genes, 
which involve modulation of RNA splicing, retention of DNA- and RNA-binding proteins, and transcription [47-49]. In addition, in these scenarios, several sequence contexts such as U1 signal and polyadenylation signal (PAS) likely have multifaceted roles in shaping the evolution by controlling transcriptional directionality, premature termination, transcriptional elongation, nuclear localization, and connection to PAXT, beyond the conventional roles in RNA splicing and polyadenylation of mRNAs [50-54].

\section{Biological Significance of Human Nuclear RNA Exosome}

RNA exosome complexes are thought to be cell-essential genes required for cell viability. Reflecting that the RNA exosome targets numerous types of RNAs, experimental depletion of RNA exosome causes complex phenotypes, including alterations in translation, chromatin regulation, genome structure, R-loop formation, DNA damage response, telomere regulation, cell viability, differentiation, and cellular senescence $[3,4,55]$. However, it remains unclear how RNA exosome depletion causes these phenotypes through direct or indirect effects. Several missense mutations in genes encoding RNA exosome components and cofactors are linked to various rare diseases, and complete loss of the RNA exosome appears to be lethal. In this section and the following section, we summarize the physiological relevance of the RNA exosome and the pathological involvement in disease conditions with particular focus on the collection of rare diseases associated with mutations in core exosome genes and cancers.

\subsection{Regulation of Genome Stability, Chromatin Structure, and DNA Damage Response}

Depletion of the RNA exosome can drastically change the localization and accumulation of multiple RNA species. As described earlier, depletion of MTR4 and ZFC3H1 induces cytoplasmic accumulation of nuclear RNAs and perturbs translation [25,33]. In the nucleus, unwanted and excess accumulation of nuclear RNA can augment R-loop formation, DNA damage response, and genome instability. The unique roles of RNA exosome in genome stability control have been demonstrated by a series of studies in B cells, which undergo activation-induced cytidine deaminase (AID)-mediated immunoglobulin heavychain (IgH) class switch recombination (CSR) and somatic hypermutation (SHM) [56-61]. In B cells, cooperation between AID and the RNA exosome, together with their physical interaction, is required for normal CSR. These findings suggest that resolution of RNA:DNA hybrids (R-loop) by the RNA exosome is essential for proper mutagenesis activity of AID, chromatin configuration, and subsequent genomic rearrangement [56-61]. In addition, the RNA exosome interacts with senataxin (SETX), an R-loop-resolving RNA helicase, and depletion of SETX yields phenotypes similar to those resulting from the depletion of RNA exosome in B cells $[62,63]$. Consistent with this, we previously reported that depletion of EXOSC 3 caused an increase in $\gamma-\mathrm{H} 2 \mathrm{AX}$ and p53 levels in mouse embryonic stem cells (mESCs) [53].

A recent analysis further demonstrated that the RNA exosome was necessary for DNA repair for homologous recombination (HR) [64]. In the context of DNA damage, the RNA exosome is essential for the clearance of long non-coding RNAs (ncRNAs) transcribed at DNA double-strand breaks (DSB)-flanking sequences that form DNA-RNA hybrids. This appears to be important for the prevention of DNA hyper-resection associated with transcription, recruitment of the ssDNA-binding protein RPA to DSB sites, and assembly of HR machinery [64]. Another recent study showed a complex interplay among ncRNA, RNA exosome, and polycomb repressive complex 2 (PRC2) in the induction of heterochromatin and transcriptional silencing, suggesting expanded roles of the RNA exosome in chromatin configuration $[65,66]$. In addition, the RNA exosome plays important roles in suppressing other unwanted RNA molecules, including expanded hexanucleotide repeat RNA in the C9orf72 gene in patients with frontotemporal lobar degeneration (FTLD) and amyotrophic lateral sclerosis (ALS) [67]. Conversely, arginine-rich toxic dipeptide repeat (DPR) proteins derived from repeat RNAs are suggested to impair the function of the RNA exosome [67]. 


\subsection{Gene Regulation and Differentiation}

Gene expression programs consist of multiple layers of feedback and feedforward regulation. This is also the case for RNA processing and RNA degradation. PABPN1 autoregulates itself by binding to an A-rich region in the $3^{\prime}$ UTRs of PABPN1 pre-mRNA, preventing splicing, and inducing nuclear decay [68]. Such post-transcriptional autoregulation is also observed for DGCR8, a central processor of miRNA precursors, whose mRNAs are destabilized by the Drosha-DGCR8 complex via the hairpin structures [69]. Thus, it is not surprising that widespread perturbation of RNA turnover by RNA exosome depletion perturbs spatio-temporal patterns of gene expression through direct and indirect effects, altering diverse cellular phenotypes, including differentiation, proliferation, and cellular senescence. In fact, together with dynamic changes in the expression levels of EXOSC components, the RNA exosome plays important roles in differentiation programs in various cell types, such as skin epidermal progenitors, erythrocytes, and mouse and human ESCs [21,53,70-75].

A study in mESCs has revealed that the transcripts that are differentially expressed between distinct differentiation states tend to be more exosome-sensitive in either state where the expression is lower than the other [74]. Thus, in conjunction with transcriptional regulation, the RNA exosome may contribute to both accentuation of cell type-specific transcriptional programs and rapid remodeling of transcriptomes during differentiation. Such interplay between transcription and RNA decay can be partly explained by the fact that depletion of the m6A writer METTL3 or the nuclear reader YTHDC1 protects chromosome-associated regulatory RNAs (carRNAs), including promoter-associated RNAs, enhancer RNAs, and repeat RNAs, from m6A-guided exosome degradation, and finally increases chromatin accessibility and activates transcription [76]. Consistent with this, m6A modification has important roles in rewiring pluripotency and differentiation programs in ESCs [77-80]. Furthermore, in acute myeloid leukemia (AML) cells, YTHDC1 binds to m6A RNAs and forms liquid-like condensates in the nucleus, and the condensates protect a set of PAXT target RNAs from degradation. The m6A-mediated protection of RNAs is a barrier to decreased cell proliferation, and increased cell death and differentiation of AML [81].

In addition, a recent report has shown that the RNA exosome-mediated RNA turnover has an important role in cellular senescence [82]. Senescent cells exhibit reduced turnover of multiple unstable RNAs, including $3^{\prime}$ extended U snRNAs and uaRNAs, short-lived mRNAs, and upregulation of the interferon-inducible genes [82]. This phenotype appears to be associated with reduced expression of RNA exosome subunits, such as DIS3L (the catalytic subunit of the cytoplasmic RNA exosome complex), EXOSC3, and EXOSC9, in several cell types. Consistently, depletion of EXOSC3 accelerated expression of multiple senescence markers and induced a senescent-like phenotype [82].

\section{Pathological Significance of Human Nuclear RNA Exosome}

\subsection{Mutations in RNA Exosome Components and Rare Diseases}

Mutations in distinct components of the RNA exosome have been linked to distinct, tissue-specific disease phenotypes, while some partly overlap [83-85]; such conditions are collectively called "exosomepathy". Mutations in EXOSC3, EXOSC8, and EXOSC9 cause several forms of autosomal-recessive neurodegenerative disease, pontocerebellar hypoplasia ( $\mathrm{PCH})$, namely, $\mathrm{PCH}$ type $1 \mathrm{~b}$ (PCH1b), $\mathrm{PCH} 1 \mathrm{c}$, and $\mathrm{PCH} 1 \mathrm{~d}$, respectively [83-85]. PCH1b with EXOSC3 mutations is characterized by atrophy of the cerebellum and pons [86]. PCH1c with EXOSC8 mutations is characterized by psychomotor deficits, cerebellar and corpus callosum hypoplasia, hypomyelination, and spinal muscular atrophy (SMA) [87]. EXOSC9 mutations are associated with PCH1d that exhibit spinal motor neuropathy and cerebellar atrophy, while the abnormalities of the pons are modest [88]. A recent study demonstrated that mutations in EXOSC5 are associated with a novel form of exosomepathy, characterized by developmental delays, short stature, cerebellar hypoplasia, and motor weakness [89]. In addition, the bi-allelic missense variant of EXOSC1 was recently linked 
to the disease condition of $\mathrm{PCH}$ [90]. Although it is possible that these overlapping phenotypes are induced via distinct mechanisms in a context-dependent manner, a link between tRNA processing and other PCH types may suggest alterations in tRNAs as underlying mechanisms of abnormalities of the cerebellum and pons in these exosomepathies. Five $\mathrm{PCH}$ types ( $\mathrm{PCH} 2 / 4 / 5 / 6 / 10)$ are associated with mutations in genes involved in processing and modification of tRNAs, such as the tRNA splicing endonuclease (TSEN) complex (TSEN2, TSEN15, TSEN34, and TSEN54), selenocysteinyl- and arginyl-tRNA synthetase (SEPSECS and RARS2, respectively), and TSEN kinase (CLP1) [91].

In contrast to these mutations, mutations in EXOSC2 are linked to a distinct syndrome, characterized by short stature, hearing loss, retinitis pigmentosa, and distinctive facies (SHRF), where the cerebellar atrophy is mild [92]. Given that mutations in pre-mRNA processing factors (PRPF3, PRPF4, PRPF6, PRPF8, PRPF31, SNRNP200, and RP9) have been linked to $15-20 \%$ of autosomal dominant retinitis pigmentosa, retinitis pigmentosa of EXOSC2-associated SHRF may be associated with misprocessing of pre-mRNAs and snRNAs [93]. As other examples, mutations in PABPN1 have been linked to oculopharyngeal muscular dystrophy (OPMD) [94]. Mutations in the NEXT components, RBM7 and ZC$\mathrm{CHC}$, have been linked to spinal motor neuropathy and familial pulmonary fibrosis with short telomere syndrome features (including bone marrow failure), respectively [95,96]. Although the underlying mechanisms appear to be different, altered expression of RBM7 is also reportedly associated with pulmonary fibrosis [97]. In addition, mutations in SKIV2L and TTC37 (components of the cytoplasmic exosome cofactor, Ski complex) have been linked to syndromic diarrhea/trichohepatoenteric syndromes (SD/THES2 and SD/THES1), respectively [98,99].

The mechanistic consequences of mutations in core exosome genes remain unclear. However, mutations in the exosome subunit appear to generally impair the assembly of the RNA exosome complex and reduce overall levels of the functional complex [83-85]. As EXOSC2 mutations may only mildly reduce the overall level of the RNA exosome, the degrees of disruption of the functional complex may partly explain the presence of the $\mathrm{PCH}$ phenotype. It is also likely that mutations in distinct core exosome genes differentially affect distinct entry paths for the RNA exosome, distinct RNA target classes, and distinct cofactors, finally leading to diverse mutation-dependent and cell type-dependent phenotypes. Furthermore, an interplay between known complex configurations and cell cycle-dependent interaction dynamics may distinguish the effects of each component on the overall behaviors of the RNA exosome [17].

\subsection{RNA Exosome and Cancer}

An inspection of CRISPR screening of 1054 cancer cell lines using DepMap showed that EXOSC1-10 and DIS3 (EXOSC11) are essential in most cancer cell lines (Figure 3a) [100,101]. PABPN1 and MTR4, as well as CBCA components and ZC3H18, also exhibit similar essentialness. In contrast, RBM7, a NEXT component, is essential in only a small fraction, and ZFC3H1 is essential in approximately half of cell lines. Consistent with this, an inspection of the genomic status of exosome components in TCGA database (cBioPortal) showed that loss-of-function or large deletions of the RNA exosome components are rare in human cancers (Figure $3 \mathrm{~b}-\mathrm{d}$ ) $[102,103]$. Of note, at a glance, amplification of EXOSC4 and $\mathrm{ZC} 3 \mathrm{H} 3$ genes are relatively frequent in certain cancer types, and clearly exhibit the co-occurrence (Figure $3 b$ ). However, these genes are located in the long arm of chromosome 8 , which is well known to possess oncogenes such as c-myc and c-mos and be frequently amplified in various cancers [104-106]; therefore, careful evaluation is required if amplification of these genes are bona fide cancer-driver. As one exception, heterozygous DIS3 mutations are recurrently observed in approximately $10-20 \%$ of patients with multiple myelomas and detected in AML and other cancer types [107-109]. Germline variants of DIS3 have also been recently identified in familial multiple myeloma [110]. DIS3 mutations are mainly located within the major ribonuclease domains of the protein and are thought to impair DIS3 catalytic activity. Although the mechanistic consequences of DIS3 mutations 
are largely unclear, a recent report has described that cancer-associated DIS3 mutations cause mitotic defects and genome instability without increased DNA damage and RNA processing defects in yeast [111]. In addition, another report described that DIS3-deficient B cells show accumulation of AID-mediated asymmetric nicks, alterations in SHM patterns, and increase in microhomology-mediated end-joining DNA repair. In DIS3-deficient B cells, altered mutation patterns and architectural defects of the IgH locus lead to decreased CSR but increased chromosomal translocations [61]. Although it is unclear whether these mechanisms work similarly in myeloma cells, AID and/or immunoglobulin expression may confer DIS3-dependent mechanisms specifically in myeloma pathogenesis.
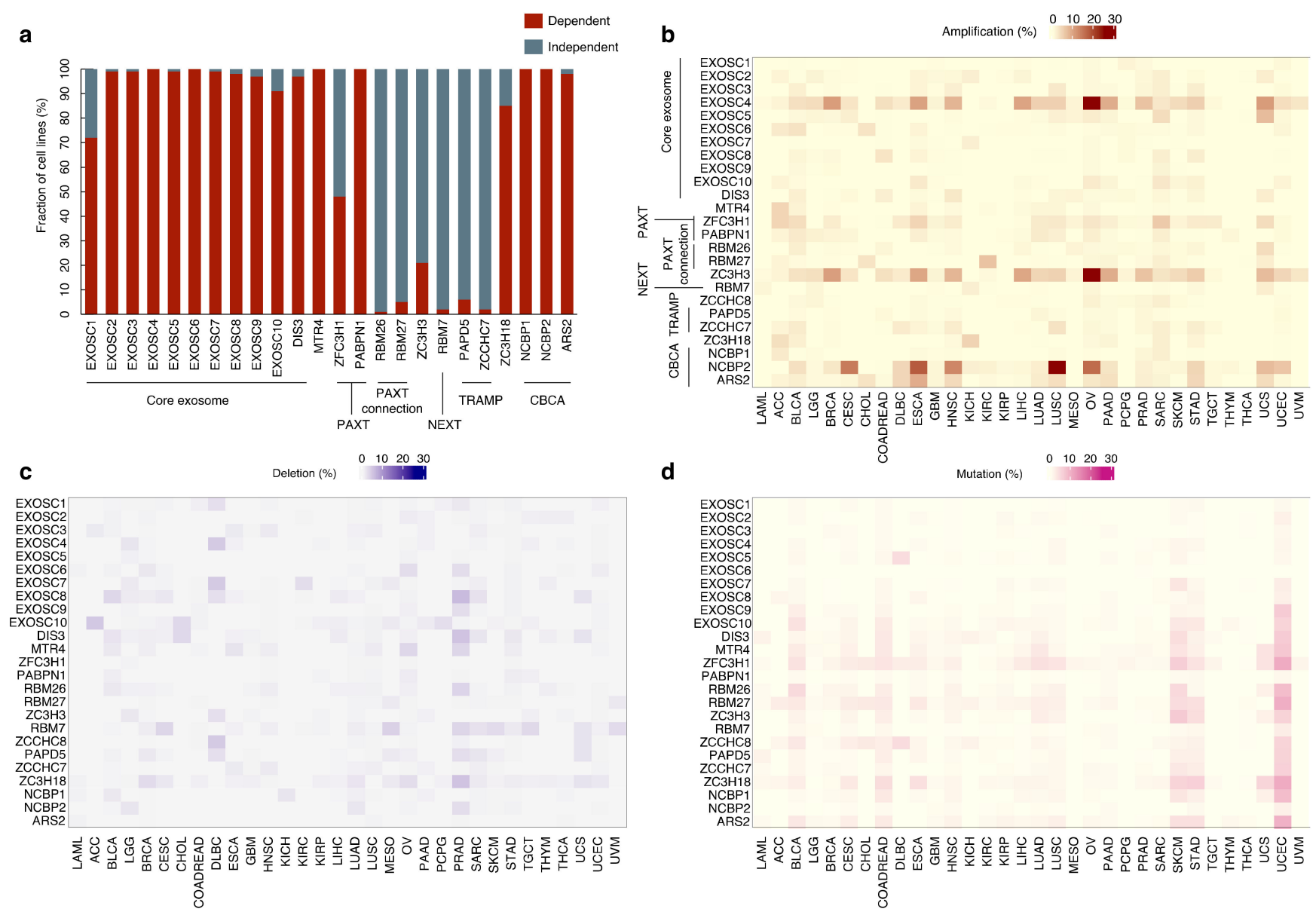

Figure 3. Dependencies on exosome-related genes in cancer cell lines and the alteration frequencies in human cancers. (a) A chart showing the percentage out of 1054 cancer cell lines, in which the dependency for a given CRISPR target gene is identified in the Cancer Dependency Map (DepMap). A cell line with a probability of dependency greater than 0.5 was considered as dependent [101]. Note that the data for a NEXT component ZCCHC8 is unavailable in DepMap. (b-d) Heatmaps showing the percentage of TCGA cases, in which (b) amplifications, (c) deletions or (d) mutations in given genes were evident. DepMap and cBioPortal were accessed in November of 2021. LAML, Acute Myeloid Leukemia; ACC, Adrenocortical Carcinoma; BLCA, Bladder Urothelial Carcinoma; LGG, Brain Lower Grade Glioma; BRCA, Breast Invasive Carcinoma; CESC, Cervical Squamous Cell Carcinoma and Endocervical Adenocarcinoma; CHOL, Cholangiocarcinoma; COADREAD, Colorectal Adenocarcinoma; DLBC, Diffuse Large B-Cell Lymphoma; ESCA, Esophageal Carcinoma; GBM, Glioblastoma Multiforme; HNSC, Head and Neck Squamous Cell Carcinoma; KICH, Kidney Chromophobe; KIRC, Kidney Renal Clear Cell Carcinoma; KIRP, Kidney Renal Papillary Cell Carcinoma; LIHC, Liver Hepatocellular Carcinoma; LUAD, Lung Adenocarcinoma; LUSC, Lung Squamous Cell Carcinoma; MESO, Mesothelioma; OV, Ovarian Serous Cystadenocarcinoma; PAAD, Pancreatic Adenocarcinoma; PCPG, Pheochromocytoma and Paraganglioma; PRAD, Prostate Adenocarcinoma; SARC, Sarcoma; SKCM, Skin Cutaneous Melanoma; STAD, Stomach Adenocarcinoma; TGCT, Testicular Germ Cell Tumors; THYM, Thymoma; THCA, Thyroid Carcinoma; UCS, Uterine Carcinosarcoma; UCEC, Uterine Corpus Endometrial Carcinoma; and UVM, Uveal Melanoma. 
A recent integrative survey of rRNA metabolism-related genes using TCGA database showed that specific upregulation of EXOSC 8 expression is driven by alterations in copy number variations (CNV) and correlates with worse prognosis in colorectal cancer [112]. In addition, upregulation of EXOSC4 and EXOSC 5 expression has been reported in colorectal cancer, in which upregulated expression of EXOSC 5 was associated with a worse prognosis $[113,114]$. A correlation between high EXOSC1 expression and poor prognosis has been reported in kidney renal clear cell carcinoma [19]. Such relationships have also been observed for various core exosome components in mantle cell lymphoma [115]. Interestingly, a recent report has described that several RNA metabolic pathways, including mRNA splicing, RNA exosome-mediated RNA decay, and m6A modification, are upregulated in the Sonic Hedgehog (SHH) subgroup of medulloblastoma, which is frequently associated with mutations in U1 snRNA, suggesting the particular importance of the RNA surveillance system in this tumor type [116].

With respect to functional consequences, EXOSC9 depletion inhibits growth and survival under various stress conditions in several cancer cell lines [117]. Along with EXOSC9 depletion, depletion of EXOSC2/EXOSC4 also attenuates stress resistance and P-body formation, which are important for stress adaptation [117]. Importantly, a low EXOSC9 target signature has been shown to correlate with poor prognosis in adrenocortical carcinoma, lung adenocarcinoma, and pancreatic adenocarcinoma [117]. In addition, MTR4, whose expression is frequently upregulated in hepatocellular carcinoma, and RBM7, whose expression is upregulated in breast cancer, promote tumor progression by modulating alternative splicing-mediated metabolic switch and stabilizing CDK1 mRNA, respectively $[118,119]$. A connection among m6A RNA methylation, RNA-binding proteins, and the RNA exosome has also been suggested in several reports $[81,120]$. Future studies may reveal the detailed contribution of the RNA exosome to cancer.

\section{Conclusions}

The present review summarizes the relationships between pervasive transcription and RNA exosome, including evolutionary crosstalk, mechanisms of RNA exosome-mediated RNA surveillance, and physiopathological effects of perturbation of RNA exosome. Cooccurrence of pervasive transcription and RNA exosome system appears to fit well with a weak selection regime, conferring evolvability to organisms based on individually weak mutations, which are promiscuous but rich sources for transcription. In addition, various phenotypes observed upon perturbation of the RNA exosome and cofactors may be viewed as functions of the RNA exosome, independent of the counterbalance system for pervasive transcription. As the RNA exosome influences genome stability, it is important to understand how the RNA exosome controls the dynamics of nuclear meso-scale structures and controls compartmentation of biochemical reactions in the nuclei. Given that various RNA molecules targeted by the RNA exosome play important roles in intracellular liquid-liquid phase separation (LLPS), the biology of biomolecular condensate and LLPS may be intimately associated with the functions of the RNA exosome [121,122]. From this perspective, the RNA exosome may not only suppress deleterious effects of cryptic transcription but also facilitate functional innovation based on multivalent weak cooperative interaction, a hallmark of LLPS-type biological reactions, through effective compartmentation of biochemical reactions [123]. A better understanding of RNA exosome involvement in pathological conditions will allow for therapeutic development targeting RNA surveillance systems.

Author Contributions: Writing, K.O. and H.I.S.; supervision, H.I.S. All authors have read and agreed to the published version of the manuscript.

Funding: This work was supported by JSPS KAKENHI Grant Numbers 19K24694 (H.I.S.), 20K15719 (K.O.), the Mochida Memorial Foundation for Medical and Pharmaceutical Research (H.I.S.), Grant for Basic Science Research Projects from the Sumitomo Foundation (H.I.S.), Mitsubishi Foundation 
(H.I.S.), Daiichi Sankyo Foundation of Life Science (H.I.S.), Uehara Memorial Foundation (H.I.S.), Takeda Science Foundation (K.O. and H.I.S.), and Hibino Foundation (K.O.).

Acknowledgments: We thank Koh Onimaru, Seiko Yoshino, and Shintaro Komatsu, and the members of the Suzuki laboratories for their discussions. The results here are in whole or part based upon data generated by the TCGA Research Network: https:/ /www.cancer.gov/tcga.

Conflicts of Interest: The authors declare no conflict of interest. The funders had no role in the design of the study; in the collection, analyses, or interpretation of data; in the writing of the manuscript, or in the decision to publish the results.

\section{References}

1. Haberle, V.; Stark, A. Eukaryotic core promoters and the functional basis of transcription initiation. Nat. Rev. Mol. Cell Biol. 2018, 19, 621-637. [CrossRef]

2. Cramer, P. Organization and regulation of gene transcription. Nature 2019, 573, 45-54. [CrossRef]

3. Ogami, K.; Chen, Y.; Manley, J.L. RNA surveillance by the nuclear RNA exosome: Mechanisms and significance. Non-Coding RNA 2018, 4, 8. [CrossRef] [PubMed]

4. Schmid, M.; Jensen, T.H. Controlling nuclear RNA levels. Nat. Rev. Genet. 2018, 19, 518-529. [CrossRef]

5. Garland, W.; Jensen, T.H. Nuclear sorting of RNA. Wiley Interdiscip. Rev. RNA 2020, 11, e1572. [CrossRef]

6. Januszyk, K.; Lima, C.D. The eukaryotic RNA exosome. Curr. Opin. Struct. Biol. 2014, 24, 132-140. [CrossRef] [PubMed]

7. Zinder, J.C.; Lima, C.D. Targeting RNA for processing or destruction by the eukaryotic RNA exosome and its cofactors. Genes Dev. 2017, 31, 88-100. [CrossRef]

8. Makino, D.L.; Conti, E. Structure determination of an 11-subunit exosome in complex with RNA by molecular replacement. Acta Crystallogr. Sect. D Biol. Crystallogr. 2013, 69, 2226-2235. [CrossRef] [PubMed]

9. Wasmuth, E.V.; Januszyk, K.; Lima, C.D. Structure of an Rrp6-RNA exosome complex bound to poly(A) RNA. Nature 2014, 511, 435-439. [CrossRef] [PubMed]

10. Makino, D.L.; Schuch, B.; Stegmann, E.; Baumgärtner, M.; Basquin, C.; Conti, E. RNA degradation paths in a 12-subunit nuclear exosome complex. Nature 2015, 524, 54-58. [CrossRef]

11. Bonneau, F.; Basquin, J.; Ebert, J.; Lorentzen, E.; Conti, E. The yeast exosome functions as a macromolecular cage to channel RNA substrates for degradation. Cell 2009, 139, 547-559. [CrossRef]

12. Liu, J.J.; Bratkowski, M.A.; Liu, X.; Niu, C.Y.; Ke, A.; Wang, H.W. Visualization of distinct substrate-recruitment pathways in the yeast exosome by EM. Nat. Struct. Mol. Biol. 2014, 21, 95-102. [CrossRef]

13. Han, J.; van Hoof, A. The RNA Exosome Channeling and Direct Access Conformations Have Distinct In Vivo Functions. Cell Rep. 2016, 16, 3348-3358. [CrossRef] [PubMed]

14. Zinder, J.C.; Wasmuth, E.V.; Lima, C.D. Nuclear RNA Exosome at 3.1 Å Reveals Substrate Specificities, RNA Paths, and Allosteric Inhibition of Rrp44/Dis3. Mol. Cell 2016, 64, 734-745. [CrossRef]

15. Gerlach, P.; Schuller, J.M.; Bonneau, F.; Basquin, J.; Reichelt, P.; Falk, S.; Conti, E. Distinct and evolutionary conserved structural features of the human nuclear exosome complex. eLife 2018, 7, e38686. [CrossRef] [PubMed]

16. Weick, E.M.; Puno, M.R.; Januszyk, K.; Zinder, J.C.; DiMattia, M.A.; Lima, C.D. Helicase-Dependent RNA Decay Illuminated by a Cryo-EM Structure of a Human Nuclear RNA Exosome-MTR4 Complex. Cell 2018, 173, 1663-1677.e1621. [CrossRef] [PubMed]

17. Dai, L.; Zhao, T.; Bisteau, X.; Sun, W.; Prabhu, N.; Lim, Y.T.; Sobota, R.M.; Kaldis, P.; Nordlund, P. Modulation of Protein-Interaction States through the Cell Cycle. Cell 2018, 173, 1481-1494.e1413. [CrossRef]

18. Fox, M.J.; Mosley, A.L. Rrp6: Integrated roles in nuclear RNA metabolism and transcription termination. Wiley Interdiscip. Rev. RNA 2016, 7, 91-104. [CrossRef] [PubMed]

19. Liu, Q.; Xiao, Q.; Sun, Z.; Wang, B.; Wang, L.; Wang, N.; Wang, K.; Song, C.; Yang, Q. Exosome component 1 cleaves singlestranded DNA and sensitizes human kidney renal clear cell carcinoma cells to poly(ADP-ribose) polymerase inhibitor. eLife 2021, 10, e69454. [CrossRef]

20. Lubas, M.; Christensen, M.S.; Kristiansen, M.S.; Domanski, M.; Falkenby, L.G.; Lykke-Andersen, S.; Andersen, J.S.; Dziembowski, A.; Jensen, T.H. Interaction profiling identifies the human nuclear exosome targeting complex. Mol. Cell 2011, 43, 624-637. [CrossRef]

21. Wu, Y.; Liu, W.; Chen, J.; Liu, S.; Wang, M.; Yang, L.; Chen, C.; Qi, M.; Xu, Y.; Qiao, Z.; et al. Nuclear Exosome Targeting Complex Core Factor Zcchc8 Regulates the Degradation of LINE1 RNA in Early Embryos and Embryonic Stem Cells. Cell Rep. 2019, 29, 2461-2472. [CrossRef]

22. Lubas, M.; Andersen, P.R.; Schein, A.; Dziembowski, A.; Kudla, G.; Jensen, T.H. The human nuclear exosome targeting complex is loaded onto newly synthesized RNA to direct early ribonucleolysis. Cell Rep. 2015, 10, 178-192. [CrossRef] [PubMed]

23. Meola, N.; Domanski, M.; Karadoulama, E.; Chen, Y.; Gentil, C.; Pultz, D.; Vitting-Seerup, K.; Lykke-Andersen, S.; Andersen, J.S.; Sandelin, A.; et al. Identification of a Nuclear Exosome Decay Pathway for Processed Transcripts. Mol. Cell 2016, 64, 520-533. [CrossRef] [PubMed] 
24. Silla, T.; Schmid, M.; Dou, Y.; Garland, W.; Milek, M.; Imami, K.; Johnsen, D.; Polak, P.; Andersen, J.S.; Selbach, M.; et al. The human ZC3H3 and RBM26/27 proteins are critical for PAXT-mediated nuclear RNA decay. Nucleic Acids Res. 2020, 48, 2518-2530. [CrossRef]

25. Ogami, K.; Richard, P.; Chen, Y.; Hoque, M.; Li, W.; Moresco, J.J.; Yates, J.R., 3rd; Tian, B.; Manley, J.L. An Mtr4/ZFC3H1 complex facilitates turnover of unstable nuclear RNAs to prevent their cytoplasmic transport and global translational repression. Genes Dev. 2017, 31, 1257-1271. [CrossRef]

26. Andersen, P.R.; Domanski, M.; Kristiansen, M.S.; Storvall, H.; Ntini, E.; Verheggen, C.; Schein, A.; Bunkenborg, J.; Poser, I.; Hallais, M.; et al. The human cap-binding complex is functionally connected to the nuclear RNA exosome. Nat. Struct. Mol. Biol. 2013, 20, 1367-1376. [CrossRef]

27. Winczura, K.; Schmid, M.; Iasillo, C.; Molloy, K.R.; Harder, L.M.; Andersen, J.S.; LaCava, J.; Jensen, T.H. Characterizing ZC3H18, a Multi-domain Protein at the Interface of RNA Production and Destruction Decisions. Cell Rep. 2018, 22, 44-58. [CrossRef]

28. Wu, G.; Schmid, M.; Rib, L.; Polak, P.; Meola, N.; Sandelin, A.; Jensen, T.H. A Two-Layered Targeting Mechanism Underlies Nuclear RNA Sorting by the Human Exosome. Cell Rep. 2020, 30, 2387-2401. [CrossRef]

29. Rambout, X.; Maquat, L.E. The nuclear cap-binding complex as choreographer of gene transcription and pre-mRNA processing. Genes Dev. 2020, 34, 1113-1127. [CrossRef] [PubMed]

30. Giacometti, S.; Benbahouche, N.E.H.; Domanski, M.; Robert, M.C.; Meola, N.; Lubas, M.; Bukenborg, J.; Andersen, J.S.; Schulze, W.M.; Verheggen, C.; et al. Mutually Exclusive CBC-Containing Complexes Contribute to RNA Fate. Cell Rep. 2017, 18, 2635-2650. [CrossRef] [PubMed]

31. Marzluff, W.F.; Koreski, K.P. Birth and Death of Histone mRNAs. Trends Genet. TIG 2017, 33, 745-759. [CrossRef] [PubMed]

32. Iasillo, C.; Schmid, M.; Yahia, Y.; Maqbool, M.A.; Descostes, N.; Karadoulama, E.; Bertrand, E.; Andrau, J.C.; Jensen, T.H. ARS2 is a general suppressor of pervasive transcription. Nucleic Acids Res. 2017, 45, 10229-10241. [CrossRef] [PubMed]

33. Ogami, K.; Manley, J.L. Mtr4/ZFC3H1 protects polysomes through nuclear RNA surveillance. Cell Cycle 2017, 16, 1999-2000. [CrossRef]

34. Fan, J.; Kuai, B.; Wu, G.; Wu, X.; Chi, B.; Wang, L.; Wang, K.; Shi, Z.; Zhang, H.; Chen, S.; et al. Exosome cofactor hMTR4 competes with export adaptor ALYREF to ensure balanced nuclear RNA pools for degradation and export. EMBO J. 2017, 36, 2870-2886. [CrossRef] [PubMed]

35. Silla, T.; Karadoulama, E.; Mąkosa, D.; Lubas, M.; Jensen, T.H. The RNA Exosome Adaptor ZFC3H1 Functionally Competes with Nuclear Export Activity to Retain Target Transcripts. Cell Rep. 2018, 23, 2199-2210. [CrossRef]

36. Wang, Y.; Fan, J.; Wang, J.; Zhu, Y.; Xu, L.; Tong, D.; Cheng, H. ZFC3H1 prevents RNA trafficking into nuclear speckles through condensation. Nucleic Acids Res. 2021, 49, 10630-10643. [CrossRef] [PubMed]

37. Richard, P.; Ogami, K.; Chen, Y.; Feng, S.; Moresco, J.J.; Yates, J.R., 3rd; Manley, J.L. NRDE-2, the human homolog of fission yeast Nrl1, prevents DNA damage accumulation in human cells. RNA Biol. 2018, 15, 868-876. [CrossRef]

38. Wang, J.; Chen, J.; Wu, G.; Zhang, H.; Du, X.; Chen, S.; Zhang, L.; Wang, K.; Fan, J.; Gao, S.; et al. NRDE2 negatively regulates exosome functions by inhibiting MTR4 recruitment and exosome interaction. Genes Dev. 2019, 33, 536-549. [CrossRef] [PubMed]

39. Palazzo, A.F.; Koonin, E.V. Functional Long Non-coding RNAs Evolve from Junk Transcripts. Cell 2020, 183, 1151-1161. [CrossRef] [PubMed]

40. Ponting, C.P. Biological function in the twilight zone of sequence conservation. BMC Biol. 2017, 15, 71. [CrossRef] [PubMed]

41. Seila, A.C.; Calabrese, J.M.; Levine, S.S.; Yeo, G.W.; Rahl, P.B.; Flynn, R.A.; Young, R.A.; Sharp, P.A. Divergent transcription from active promoters. Science 2008, 322, 1849-1851. [CrossRef]

42. Iglesias, N.; Moazed, D. Silencing repetitive DNA. eLife 2017, 6, e29503. [CrossRef]

43. Lukeš, J.; Archibald, J.M.; Keeling, P.J.; Doolittle, W.F.; Gray, M.W. How a neutral evolutionary ratchet can build cellular complexity. IUBMB Life 2011, 63, 528-537. [CrossRef]

44. Gould, S.J.; Lewontin, R.C. The spandrels of San Marco and the Panglossian paradigm: A critique of the adaptationist programme. Proc. R. Soc. Lond. Ser. B Biol. Sci. 1979, 205, 581-598. [CrossRef]

45. Chen, S.; Krinsky, B.H.; Long, M. New genes as drivers of phenotypic evolution. Nat. Rev. Genet. 2013, 14, 645-660. [CrossRef]

46. Long, M.; VanKuren, N.W.; Chen, S.; Vibranovski, M.D. New gene evolution: Little did we know. Annu. Rev. Genet. 2013, 47, 307-333. [CrossRef] [PubMed]

47. Lai, F.; Orom, U.A.; Cesaroni, M.; Beringer, M.; Taatjes, D.J.; Blobel, G.A.; Shiekhattar, R. Activating RNAs associate with Mediator to enhance chromatin architecture and transcription. Nature 2013, 494, 497-501. [CrossRef]

48. Sigova, A.A.; Abraham, B.J.; Ji, X.; Molinie, B.; Hannett, N.M.; Guo, Y.E.; Jangi, M.; Giallourakis, C.C.; Sharp, P.A.; Young, R.A. Transcription factor trapping by RNA in gene regulatory elements. Science 2015, 350, 978-981. [CrossRef]

49. Engreitz, J.M.; Haines, J.E.; Perez, E.M.; Munson, G.; Chen, J.; Kane, M.; McDonel, P.E.; Guttman, M.; Lander, E.S. Local regulation of gene expression by lncRNA promoters, transcription and splicing. Nature 2016, 539, 452-455. [CrossRef] [PubMed]

50. Kaida, D.; Berg, M.G.; Younis, I.; Kasim, M.; Singh, L.N.; Wan, L.; Dreyfuss, G. U1 snRNP protects pre-mRNAs from premature cleavage and polyadenylation. Nature 2010, 468, 664-668. [CrossRef] [PubMed]

51. Almada, A.E.; Wu, X.; Kriz, A.J.; Burge, C.B.; Sharp, P.A. Promoter directionality is controlled by U1 snRNP and polyadenylation signals. Nature 2013, 499, 360-363. [CrossRef] 
52. Ntini, E.; Järvelin, A.I.; Bornholdt, J.; Chen, Y.; Boyd, M.; Jørgensen, M.; Andersson, R.; Hoof, I.; Schein, A.; Andersen, P.R.; et al. Polyadenylation site-induced decay of upstream transcripts enforces promoter directionality. Nat. Struct. Mol. Biol. 2013, 20, 923-928. [CrossRef]

53. Chiu, A.C.; Suzuki, H.I.; Wu, X.; Mahat, D.B.; Kriz, A.J.; Sharp, P.A. Transcriptional Pause Sites Delineate Stable NucleosomeAssociated Premature Polyadenylation Suppressed by U1 snRNP. Mol. Cell 2018, 69, 648-663.e647. [CrossRef]

54. Yin, Y.; Lu, J.Y.; Zhang, X.; Shao, W.; Xu, Y.; Li, P.; Hong, Y.; Cui, L.; Shan, G.; Tian, B.; et al. U1 snRNP regulates chromatin retention of noncoding RNAs. Nature 2020, 580, 147-150. [CrossRef]

55. Kilchert, C.; Wittmann, S.; Vasiljeva, L. The regulation and functions of the nuclear RNA exosome complex. Nat. Reviews. Mol. Cell Biol. 2016, 17, 227-239. [CrossRef]

56. Basu, U.; Meng, F.L.; Keim, C.; Grinstein, V.; Pefanis, E.; Eccleston, J.; Zhang, T.; Myers, D.; Wasserman, C.R.; Wesemann, D.R.; et al. The RNA exosome targets the AID cytidine deaminase to both strands of transcribed duplex DNA substrates. Cell 2011, 144, 353-363. [CrossRef] [PubMed]

57. Pefanis, E.; Wang, J.; Rothschild, G.; Lim, J.; Chao, J.; Rabadan, R.; Economides, A.N.; Basu, U. Noncoding RNA transcription targets AID to divergently transcribed loci in B cells. Nature 2014, 514, 389-393. [CrossRef] [PubMed]

58. Pefanis, E.; Wang, J.; Rothschild, G.; Lim, J.; Kazadi, D.; Sun, J.; Federation, A.; Chao, J.; Elliott, O.; Liu, Z.P.; et al. RNA exosome-regulated long non-coding RNA transcription controls super-enhancer activity. Cell 2015, 161, 774-789. [CrossRef]

59. Lim, J.; Giri, P.K.; Kazadi, D.; Laffleur, B.; Zhang, W.; Grinstein, V.; Pefanis, E.; Brown, L.M.; Ladewig, E.; Martin, O.; et al. Nuclear Proximity of Mtr4 to RNA Exosome Restricts DNA Mutational Asymmetry. Cell 2017, 169, 523-537. [CrossRef]

60. Rothschild, G.; Zhang, W.; Lim, J.; Giri, P.K.; Laffleur, B.; Chen, Y.; Fang, M.; Chen, Y.; Nair, L.; Liu, Z.P.; et al. Noncoding RNA transcription alters chromosomal topology to promote isotype-specific class switch recombination. Sci. Immunol. 2020, 5. [CrossRef] [PubMed]

61. Laffleur, B.; Lim, J.; Zhang, W.; Chen, Y.; Pefanis, E.; Bizarro, J.; Batista, C.R.; Wu, L.; Economides, A.N.; Wang, J.; et al. Noncoding RNA processing by DIS3 regulates chromosomal architecture and somatic hypermutation in B cells. Nat. Genet. 2021, 53, 230-242. [CrossRef]

62. Richard, P.; Feng, S.; Manley, J.L. A SUMO-dependent interaction between Senataxin and the exosome, disrupted in the neurodegenerative disease AOA2, targets the exosome to sites of transcription-induced DNA damage. Genes Dev. 2013, 27, 2227-2232. [CrossRef] [PubMed]

63. Kazadi, D.; Lim, J.; Rothschild, G.; Grinstein, V.; Laffleur, B.; Becherel, O.; Lavin, M.J.; Basu, U. Effects of senataxin and RNA exosome on B-cell chromosomal integrity. Heliyon 2020, 6, e03442. [CrossRef] [PubMed]

64. Domingo-Prim, J.; Endara-Coll, M.; Bonath, F.; Jimeno, S.; Prados-Carvajal, R.; Friedländer, M.R.; Huertas, P.; Visa, N. EXOSC10 is required for RPA assembly and controlled DNA end resection at DNA double-strand breaks. Nat. Commun. 2019, $10,2135$. [CrossRef]

65. Singh, I.; Contreras, A.; Cordero, J.; Rubio, K.; Dobersch, S.; Günther, S.; Jeratsch, S.; Mehta, A.; Krüger, M.; Graumann, J.; et al. MiCEE is a ncRNA-protein complex that mediates epigenetic silencing and nucleolar organization. Nat. Genet. 2018, 50, 990-1001. [CrossRef] [PubMed]

66. Garland, W.; Comet, I.; Wu, M.; Radzisheuskaya, A.; Rib, L.; Vitting-Seerup, K.; Lloret-Llinares, M.; Sandelin, A.; Helin, K.; Jensen, T.H. A Functional Link between Nuclear RNA Decay and Transcriptional Control Mediated by the Polycomb Repressive Complex 2. Cell Rep. 2019, 29, 1800-1811.e1806. [CrossRef]

67. Kawabe, Y.; Mori, K.; Yamashita, T.; Gotoh, S.; Ikeda, M. The RNA exosome complex degrades expanded hexanucleotide repeat RNA in C9orf72 FTLD/ALS. EMBO J. 2020, 39, e102700. [CrossRef] [PubMed]

68. Bergeron, D.; Pal, G.; Beaulieu, Y.B.; Chabot, B.; Bachand, F. Regulated Intron Retention and Nuclear Pre-mRNA Decay Contribute to PABPN1 Autoregulation. Mol. Cell. Biol. 2015, 35, 2503-2517. [CrossRef] [PubMed]

69. Han, J.; Pedersen, J.S.; Kwon, S.C.; Belair, C.D.; Kim, Y.K.; Yeom, K.H.; Yang, W.Y.; Haussler, D.; Blelloch, R.; Kim, V.N. Posttranscriptional crossregulation between Drosha and DGCR8. Cell 2009, 136, 75-84. [CrossRef]

70. Fraga de Andrade, I.; Mehta, C.; Bresnick, E.H. Post-transcriptional control of cellular differentiation by the RNA exosome complex. Nucleic Acids Res. 2020, 48, 11913-11928. [CrossRef] [PubMed]

71. Mistry, D.S.; Chen, Y.; Sen, G.L. Progenitor function in self-renewing human epidermis is maintained by the exosome. Cell Stem Cell 2012, 11, 127-135. [CrossRef] [PubMed]

72. McIver, S.C.; Kang, Y.A.; DeVilbiss, A.W.; O’Driscoll, C.A.; Ouellette, J.N.; Pope, N.J.; Camprecios, G.; Chang, C.J.; Yang, D.; Bouhassira, E.E.; et al. The exosome complex establishes a barricade to erythroid maturation. Blood 2014, 124, $2285-2297$. [CrossRef]

73. McIver, S.C.; Katsumura, K.R.; Davids, E.; Liu, P.; Kang, Y.A.; Yang, D.; Bresnick, E.H. Exosome complex orchestrates developmental signaling to balance proliferation and differentiation during erythropoiesis. eLife 2016, 5, e17877. [CrossRef] [PubMed]

74. Lloret-Llinares, M.; Karadoulama, E.; Chen, Y.; Wojenski, L.A.; Villafano, G.J.; Bornholdt, J.; Andersson, R.; Core, L.; Sandelin, A.; Jensen, T.H. The RNA exosome contributes to gene expression regulation during stem cell differentiation. Nucleic Acids Res. 2018, 46, 11502-11513. [CrossRef] [PubMed]

75. Belair, C.; Sim, S.; Kim, K.Y.; Tanaka, Y.; Park, I.H.; Wolin, S.L. The RNA exosome nuclease complex regulates human embryonic stem cell differentiation. J. Cell Biol. 2019, 218, 2564-2582. [CrossRef] [PubMed] 
76. Liu, J.; Dou, X.; Chen, C.; Chen, C.; Liu, C.; Xu, M.M.; Zhao, S.; Shen, B.; Gao, Y.; Han, D.; et al. N (6)-methyladenosine of chromosome-associated regulatory RNA regulates chromatin state and transcription. Science 2020, 367, 580-586. [CrossRef] [PubMed]

77. Wang, Y.; Li, Y.; Toth, J.I.; Petroski, M.D.; Zhang, Z.; Zhao, J.C. N6-methyladenosine modification destabilizes developmental regulators in embryonic stem cells. Nat. Cell Biol. 2014, 16, 191-198. [CrossRef]

78. Batista, P.J.; Molinie, B.; Wang, J.; Qu, K.; Zhang, J.; Li, L.; Bouley, D.M.; Lujan, E.; Haddad, B.; Daneshvar, K.; et al. m(6)A RNA modification controls cell fate transition in mammalian embryonic stem cells. Cell Stem Cell 2014, 15, 707-719. [CrossRef] [PubMed]

79. Geula, S.; Moshitch-Moshkovitz, S.; Dominissini, D.; Mansour, A.A.; Kol, N.; Salmon-Divon, M.; Hershkovitz, V.; Peer, E.; Mor, N.; Manor, Y.S.; et al. Stem cells. m6A mRNA methylation facilitates resolution of naïve pluripotency toward differentiation. Science 2015, 347, 1002-1006. [CrossRef] [PubMed]

80. Chen, T.; Hao, Y.J.; Zhang, Y.; Li, M.M.; Wang, M.; Han, W.; Wu, Y.; Lv, Y.; Hao, J.; Wang, L.; et al. m(6)A RNA methylation is regulated by microRNAs and promotes reprogramming to pluripotency. Cell Stem Cell 2015, 16, 289-301. [CrossRef] [PubMed]

81. Cheng, Y.; Xie, W.; Pickering, B.F.; Chu, K.L.; Savino, A.M.; Yang, X.; Luo, H.; Nguyen, D.T.; Mo, S.; Barin, E.; et al. N(6)Methyladenosine on mRNA facilitates a phase-separated nuclear body that suppresses myeloid leukemic differentiation. Cancer Cell 2021, 39, 958-972. [CrossRef] [PubMed]

82. Mullani, N.; Porozhan, Y.; Mangelinck, A.; Rachez, C.; Costallat, M.; Batsché, E.; Goodhardt, M.; Cenci, G.; Mann, C.; Muchardt, C. Reduced RNA turnover as a driver of cellular senescence. Life Sci. Alliance 2021, 4. [CrossRef] [PubMed]

83. De Amorim, J.; Slavotinek, A.; Fasken, M.B.; Corbett, A.H.; Morton, D.J. Modeling Pathogenic Variants in the RNA Exosome. RNA Dis. 2020, 7, e1166.

84. Morton, D.J.; Kuiper, E.G.; Jones, S.K.; Leung, S.W.; Corbett, A.H.; Fasken, M.B. The RNA exosome and RNA exosome-linked disease. RNA 2018, 24, 127-142. [CrossRef] [PubMed]

85. Fasken, M.B.; Morton, D.J.; Kuiper, E.G.; Jones, S.K.; Leung, S.W.; Corbett, A.H. The RNA Exosome and Human Disease. Methods Mol. Biol. 2020, 2062, 3-33. [CrossRef]

86. Wan, J.; Yourshaw, M.; Mamsa, H.; Rudnik-Schöneborn, S.; Menezes, M.P.; Hong, J.E.; Leong, D.W.; Senderek, J.; Salman, M.S.; Chitayat, D.; et al. Mutations in the RNA exosome component gene EXOSC3 cause pontocerebellar hypoplasia and spinal motor neuron degeneration. Nat. Genet. 2012, 44, 704-708. [CrossRef] [PubMed]

87. Boczonadi, V.; Müller, J.S.; Pyle, A.; Munkley, J.; Dor, T.; Quartararo, J.; Ferrero, I.; Karcagi, V.; Giunta, M.; Polvikoski, T.; et al. EXOSC8 mutations alter mRNA metabolism and cause hypomyelination with spinal muscular atrophy and cerebellar hypoplasia. Nat. Commun. 2014, 5, 4287. [CrossRef]

88. Burns, D.T.; Donkervoort, S.; Müller, J.S.; Knierim, E.; Bharucha-Goebel, D.; Faqeih, E.A.; Bell, S.K.; AlFaifi, A.Y.; Monies, D.; Millan, F.; et al. Variants in EXOSC9 Disrupt the RNA Exosome and Result in Cerebellar Atrophy with Spinal Motor Neuronopathy. Am. J. Hum. Genet. 2018, 102, 858-873. [CrossRef] [PubMed]

89. Slavotinek, A.; Misceo, D.; Htun, S.; Mathisen, L.; Frengen, E.; Foreman, M.; Hurtig, J.E.; Enyenihi, L.; Sterrett, M.C.; Leung, S.W.; et al. Biallelic variants in the RNA exosome gene EXOSC5 are associated with developmental delays, short stature, cerebellar hypoplasia and motor weakness. Hum. Mol. Genet. 2020, 29, 2218-2239. [CrossRef]

90. Somashekar, P.H.; Kaur, P.; Stephen, J.; Guleria, V.S.; Kadavigere, R.; Girisha, K.M.; Bielas, S.; Upadhyai, P.; Shukla, A. Bi-allelic missense variant, p.Ser35Leu in EXOSC1 is associated with pontocerebellar hypoplasia. Clin. Genet. 2021, 99, 594-600. [CrossRef] [PubMed]

91. Van Dijk, T.; Baas, F.; Barth, P.G.; Poll-The, B.T. What's new in pontocerebellar hypoplasia? An update on genes and subtypes. Orphanet J. Rare Dis. 2018, 13, 92. [CrossRef] [PubMed]

92. Di Donato, N.; Neuhann, T.; Kahlert, A.K.; Klink, B.; Hackmann, K.; Neuhann, I.; Novotna, B.; Schallner, J.; Krause, C.; Glass, I.A.; et al. Mutations in EXOSC2 are associated with a novel syndrome characterised by retinitis pigmentosa, progressive hearing loss, premature ageing, short stature, mild intellectual disability and distinctive gestalt. J. Med. Genet. 2016, 53, 419-425. [CrossRef] [PubMed]

93. Yang, C.; Georgiou, M.; Atkinson, R.; Collin, J.; Al-Aama, J.; Nagaraja-Grellscheid, S.; Johnson, C.; Ali, R.; Armstrong, L.; Mozaffari-Jovin, S.; et al. Pre-mRNA Processing Factors and Retinitis Pigmentosa: RNA Splicing and Beyond. Front. Cell Dev. Biol. 2021, 9, 700276. [CrossRef]

94. Brais, B.; Bouchard, J.P.; Xie, Y.G.; Rochefort, D.L.; Chrétien, N.; Tomé, F.M.; Lafrenière, R.G.; Rommens, J.M.; Uyama, E.; Nohira, O.; et al. Short GCG expansions in the PABP2 gene cause oculopharyngeal muscular dystrophy. Nat. Genet. 1998, 18, 164-167. [CrossRef] [PubMed]

95. Giunta, M.; Edvardson, S.; Xu, Y.; Schuelke, M.; Gomez-Duran, A.; Boczonadi, V.; Elpeleg, O.; Müller, J.S.; Horvath, R. Altered RNA metabolism due to a homozygous RBM7 mutation in a patient with spinal motor neuropathy. Hum. Mol. Genet. 2016, 25, 2985-2996. [CrossRef] [PubMed]

96. Gable, D.L.; Gaysinskaya, V.; Atik, C.C.; Talbot, C.C., Jr.; Kang, B.; Stanley, S.E.; Pugh, E.W.; Amat-Codina, N.; Schenk, K.M.; Arcasoy, M.O.; et al. ZCCHC8, the nuclear exosome targeting component, is mutated in familial pulmonary fibrosis and is required for telomerase RNA maturation. Genes Dev. 2019, 33, 1381-1396. [CrossRef] 
97. Fukushima, K.; Satoh, T.; Sugihara, F.; Sato, Y.; Okamoto, T.; Mitsui, Y.; Yoshio, S.; Li, S.; Nojima, S.; Motooka, D.; et al. Dysregulated Expression of the Nuclear Exosome Targeting Complex Component Rbm7 in Nonhematopoietic Cells Licenses the Development of Fibrosis. Immunity 2020, 52, 542-556. [CrossRef] [PubMed]

98. Fabre, A.; Charroux, B.; Martinez-Vinson, C.; Roquelaure, B.; Odul, E.; Sayar, E.; Smith, H.; Colomb, V.; Andre, N.; Hugot, J.P.; et al. SKIV2L mutations cause syndromic diarrhea, or trichohepatoenteric syndrome. Am. J. Hum. Genet. 2012, 90, 689-692. [CrossRef] [PubMed]

99. Hartley, J.L.; Zachos, N.C.; Dawood, B.; Donowitz, M.; Forman, J.; Pollitt, R.J.; Morgan, N.V.; Tee, L.; Gissen, P.; Kahr, W.H.; et al. Mutations in TTC37 cause trichohepatoenteric syndrome (phenotypic diarrhea of infancy). Gastroenterology 2010, 138, 2388-2398. [CrossRef]

100. Meyers, R.M.; Bryan, J.G.; McFarland, J.M.; Weir, B.A.; Sizemore, A.E.; Xu, H.; Dharia, N.V.; Montgomery, P.G.; Cowley, G.S.; Pantel, S.; et al. Computational correction of copy number effect improves specificity of CRISPR-Cas9 essentiality screens in cancer cells. Nat. Genet. 2017, 49, 1779-1784. [CrossRef] [PubMed]

101. Dempster, J.M.; Boyle, I.; Vazquez, F.; Root, D.; Boehm, J.S.; Hahn, W.C.; Tsherniak, A.; McFarland, J.M. Chronos: A CRISPR cell population dynamics model. bioRxiv 2021. [CrossRef]

102. Cerami, E.; Gao, J.; Dogrusoz, U.; Gross, B.E.; Sumer, S.O.; Aksoy, B.A.; Jacobsen, A.; Byrne, C.J.; Heuer, M.L.; Larsson, E.; et al. The cBio cancer genomics portal: An open platform for exploring multidimensional cancer genomics data. Cancer Discov. 2012, 2, 401-404. [CrossRef] [PubMed]

103. Gao, J.; Aksoy, B.A.; Dogrusoz, U.; Dresdner, G.; Gross, B.; Sumer, S.O.; Sun, Y.; Jacobsen, A.; Sinha, R.; Larsson, E.; et al. Integrative analysis of complex cancer genomics and clinical profiles using the cBioPortal. Sci. Signal. 2013, 6, pl1. [CrossRef]

104. Kang, J.U. Chromosome 8q as the most frequent target for amplification in early gastric carcinoma. Oncol. Lett. 2014, 7, 1139-1143. [CrossRef] [PubMed]

105. Neel, B.G.; Jhanwar, S.C.; Chaganti, R.S.; Hayward, W.S. Two human c-onc genes are located on the long arm of chromosome 8. Proc. Natl. Acad. Sci. USA 1982, 79, 7842-7846. [CrossRef] [PubMed]

106. Baykara, O.; Bakir, B.; Buyru, N.; Kaynak, K.; Dalay, N. Amplification of chromosome 8 genes in lung cancer. J. Cancer 2015, 6, 270-275. [CrossRef] [PubMed]

107. Chapman, M.A.; Lawrence, M.S.; Keats, J.J.; Cibulskis, K.; Sougnez, C.; Schinzel, A.C.; Harview, C.L.; Brunet, J.P.; Ahmann, G.J.; Adli, M.; et al. Initial genome sequencing and analysis of multiple myeloma. Nature 2011, 471, 467-472. [CrossRef] [PubMed]

108. Ding, L.; Ley, T.J.; Larson, D.E.; Miller, C.A.; Koboldt, D.C.; Welch, J.S.; Ritchey, J.K.; Young, M.A.; Lamprecht, T.; McLellan, M.D.; et al. Clonal evolution in relapsed acute myeloid leukaemia revealed by whole-genome sequencing. Nature 2012, 481, 506-510. [CrossRef]

109. Lionetti, M.; Barbieri, M.; Todoerti, K.; Agnelli, L.; Fabris, S.; Tonon, G.; Segalla, S.; Cifola, I.; Pinatel, E.; Tassone, P.; et al. A compendium of DIS3 mutations and associated transcriptional signatures in plasma cell dyscrasias. Oncotarget 2015, 6, 26129-26141. [CrossRef]

110. Pertesi, M.; Vallée, M.; Wei, X.; Revuelta, M.V.; Galia, P.; Demangel, D.; Oliver, J.; Foll, M.; Chen, S.; Perrial, E.; et al. Exome sequencing identifies germline variants in DIS3 in familial multiple myeloma. Leukemia 2019, 33, 2324-2330. [CrossRef] [PubMed]

111. Milbury, K.L.; Paul, B.; Lari, A.; Fowler, C.; Montpetit, B.; Stirling, P.C. Exonuclease domain mutants of yeast DIS3 display genome instability. Nucleus 2019, 10, 21-32. [CrossRef] [PubMed]

112. Cui, K.; Liu, C.; Li, X.; Zhang, Q.; Li, Y. Comprehensive characterization of the rRNA metabolism-related genes in human cancer. Oncogene 2020, 39, 786-800. [CrossRef]

113. Pan, Y.; Tong, J.H.M.; Kang, W.; Lung, R.W.M.; Chak, W.P.; Chung, L.Y.; Wu, F.; Li, H.; Yu, J.; Chan, A.W.H.; et al. EXOSC4 functions as a potential oncogene in development and progression of colorectal cancer. Mol. Carcinog. 2018, 57, 1780-1791. [CrossRef] [PubMed]

114. Pan, H.; Pan, J.; Song, S.; Ji, L.; Lv, H.; Yang, Z. EXOSC5 as a Novel Prognostic Marker Promotes Proliferation of Colorectal Cancer via Activating the ERK and AKT Pathways. Front. Oncol. 2019, 9, 643. [CrossRef]

115. Zhang, W.; Zhu, J.; He, X.; Liu, X.; Li, J.; Li, W.; Yang, P.; Wang, J.; Hu, K.; Zhang, X.; et al. Exosome complex genes mediate RNA degradation and predict survival in mantle cell lymphoma. Oncol. Lett. 2019, 18, 5119-5128. [CrossRef] [PubMed]

116. Kp, M.; Kumar, A.; Biswas, D.; Moiyadi, A.; Shetty, P.; Gupta, T.; Epari, S.; Shirsat, N.; Srivastava, S. The proteomic analysis shows enrichment of RNA surveillance pathways in adult SHH and extensive metabolic reprogramming in Group 3 medulloblastomas. Brain Tumor Pathol. 2021, 38, 96-108. [CrossRef] [PubMed]

117. Yoshino, S.; Matsui, Y.; Fukui, Y.; Seki, M.; Yamaguchi, K.; Kanamori, A.; Saitoh, Y.; Shimamura, T.; Suzuki, Y.; Furukawa, Y.; et al. EXOSC9 depletion attenuates P-body formation, stress resistance, and tumorigenicity of cancer cells. Sci. Rep. 2020, $10,9275$. [CrossRef] [PubMed]

118. Yu, L.; Kim, J.; Jiang, L.; Feng, B.; Ying, Y.; Ji, K.Y.; Tang, Q.; Chen, W.; Mai, T.; Dou, W.; et al. MTR4 drives liver tumorigenesis by promoting cancer metabolic switch through alternative splicing. Nat. Commun. 2020, 11, 708. [CrossRef] [PubMed]

119. Xi, P.W.; Zhang, X.; Zhu, L.; Dai, X.Y.; Cheng, L.; Hu, Y.; Shi, L.; Wei, J.F.; Ding, Q. Oncogenic action of the exosome cofactor RBM7 by stabilization of CDK1 mRNA in breast cancer. NPJ Breast Cancer 2020,6, 58. [CrossRef]

120. Fish, L.; Navickas, A.; Culbertson, B.; Xu, Y.; Nguyen, H.C.B.; Zhang, S.; Hochman, M.; Okimoto, R.; Dill, B.D.; Molina, H.; et al. Nuclear TARBP2 Drives Oncogenic Dysregulation of RNA Splicing and Decay. Mol. Cell 2019, 75, 967-981.e969. [CrossRef] [PubMed] 
121. Banani, S.F.; Lee, H.O.; Hyman, A.A.; Rosen, M.K. Biomolecular condensates: Organizers of cellular biochemistry. Nat. Reviews. Mol. Cell Biol. 2017, 18, 285-298. [CrossRef] [PubMed]

122. Sharp, P.A.; Chakraborty, A.K.; Henninger, J.E.; Young, R.A. RNA in formation and regulation of transcriptional condensates. RNA 2021, rna-078997. [CrossRef] [PubMed]

123. Gao, A.; Shrinivas, K.; Lepeudry, P.; Suzuki, H.I.; Sharp, P.A.; Chakraborty, A.K. Evolution of weak cooperative interactions for biological specificity. Proc. Natl. Acad. Sci. USA 2018, 115, E11053-E11060. [CrossRef] [PubMed] 